GEORG LEIDENBERGER

UNIVERSIDAD AUTÓNOMA METROPOLITANA-CUAJIMALPA

\title{
Tres revistas mexicanas de arquitectura \\ Portavoces de la modernidad, 1923-1950
}

$\mathrm{E}$

N eSTe TRABajo SE EXAMINAN TRES REVISTAS protagónicas de arquitectura moderna que circularon durante las primeras tres décadas de la posrevolución mexicana: 1920, 1930 y 1940. Cada una de estas publicaciones ofrece un punto de entrada para ver cómo los profesionales mexicanos tomaban posición frente al movimiento moderno, expresando desde reacciones defensivas o conservadoras hasta disposiciones selectivas pero abiertas a las corrientes transatlánticas. Al enfrentar los aires modernistas que llegaban sobre todo de Europa, cada casa editorial tenía que equilibrar su interés en abrirse al "mundo" con su compromiso con el proyecto cultural y político delineado a continuación de la Revolución mexicana. De acuerdo con los postulados de este proyecto, México se regeneraría como nación mediante una búsqueda de sus propias raíces y tradiciones y al mismo tiempo contrarrestaría la actitud asimilacionista que supuestamente había prevalecido durante las décadas porfirianas. Había que orientar el proyecto cultural nacionalista hacia la satisfacción de las carencias de la sociedad posrevolucionaria, entendidas éstas primero como espirituales (Vasconcelos), y, desde los años treinta, como materiales. En el ámbito de la arquitectura, se postuló la urgencia de orientar la construcción hacia las necesidades de las masas campesinas y obreras: construir viviendas obreras, escuelas rurales, hospitales y centros sindicales. Veremos cómo cada revista ubicaba las nuevas corrientes modernistas - por definición, cosmopolitas - en este contexto posrevolucionario, en el que predominaban las actitudes nacionalistas y social-materialistas. Las pos- 
turas editoriales variaban, según las preferencias estéticas — si se favorecía o no el lenguaje moderno - o políticas — si la construcción moderna era considerada apta para llevar a cabo una entendida misión social posrevolucionaria y para satisfacer las necesidades inmediatas de la reconstrucción nacional. ${ }^{\text {I }}$

Tales visiones se circunscribían al marco institucional de cada publicación, el cual variaba para cada revista: la primera, El Arquitecto (I923-I933), estaba asociada al gremio profesional, la Sociedad de Arquitectos Mexicanos (sAm); ${ }^{2}$ la segunda, Cemento (1925-1930), que luego se publicó como Tolteca (I929-I932), fue vocera de la industria privada, del Comité para Propagar el Uso del Cemento Portland, y la última, Arquitectura-México (I938-I978), la produjo un protagonista de la arquitectura nacional, Mario Pani, junto con otros miembros de su familia con amplia visibilidad en la política nacional (véase la tabla I). ${ }^{3}$ En este artículo pretendemos señalar las posibilidades y los límites que cada contexto institucional imponía sobre el contenido y la existencia de cada revista. Insistimos en que cada institución perseguía intereses inmediatos particulares que se reflejaban en la cobertura de su respectiva publicación. El gremio, la industria y la "gran familia" promovían gustos e intereses — gustos por cierta forma de "hacer arquitectura" e intereses en convencer a determinado público lector de estas predilecciones - , con el fin de vender los servicios del arquitecto en la construcción, por una parte, y, por la otra, para asentar la legitimidad de la profesión. Como veremos, la borrosa línea entre contenido e intereses se reflejaba en la tendencia a mezclar artículos y exposiciones "de fondo" con la publicidad.

I. Las revistas de arquitectura mexicana no han sido objeto de un estudio sistemático. Un texto que aborda sintéticamente el tema es el de Louise Noelle, "La arquitectura mexicana en las publicaciones periódicas del siglo xx", en www.revistas.unam.mx/index.php/bitacora/ article/view/25I05; consultado en diciembre de 2010. Una breve compilación acerca de las publicaciones de arquitectura se encuentra en Ramón Gutiérrez, "Las revistas de arquitectura de América Latina”, en Ramón Gutiérrez et al., Revistas de arquitectura de América Latina, 1900-2000, Puerto Rico, Centro de Documentación de Arquitectura Latinoamericana, 200I. Las revistas aquí estudiadas no se ubican en un acervo unificado sino en varios lugares, y pocas veces se encuentran todos los volúmenes completos. Dada esta situación, ha sido sumamente útil tener acceso a la versión digitalizada de una de tales revistas en Carlos Ríos Garza (ed.), "Revista Arquitectura-México 1938-1978”, Raices Digital, en Fuentes para la historia de la arquitectura contemporánea, Universidad Nacional Autónoma de México-Facultad de Arquitectura, 2008, núm. 6, edición digital.

2. Al mismo tiempo, la SAM y sus líderes publicaron semanalmente en el diario Excélsior "La Sección de Arquitectura”. Aunque esta publicación escapa del género de la revista, por su cercanía al proyecto editorial del gremio será analizada aquí junto con El Arquitecto.

3. Cfr. ${ }^{* *}$ de la tabla I. 
TRES REVISTAS MEXICANAS DE ARQUITECTURA

Tabla I. Las revistas de arquitectura analizadas

\begin{tabular}{|l|l|l|l|}
\hline Revista & Temporalidad & $\begin{array}{l}\text { Editorial / institución / } \\
\text { patrocinador }\end{array}$ & Editor / director \\
\hline $\begin{array}{l}\text { El Arquitecto* } \\
\text { I923-I933 }\end{array}$ & $\begin{array}{l}\text { Sociedad de Arquitectos } \\
\text { Mexicanos (sAM) }\end{array}$ & $\begin{array}{l}\text { Alfonso Pallares (años } \\
\text { veinte) e Ignacio de } \\
\text { Miranda (ańos treinta) }\end{array}$ \\
\hline $\begin{array}{l}\text { "La Sección de } \\
\text { Arquitectura",Excélsior }\end{array}$ & I922-I93I & Periódico Excélsior / sAM & $\begin{array}{l}\text { Guillermo Zárraga, } \\
\text { Juan Galindo Pimentel, } \\
\text { Bernardo Calderón y } \\
\text { Caso, Alfonso Pallares } \\
\text { Bernabé León de la } \\
\text { Barra }\end{array}$ \\
\hline $\begin{array}{l}\text { Cemento } \\
\text { Tolteca }\end{array}$ & $\begin{array}{l}\text { I925-I930 } \\
\text { I929-1932 }\end{array}$ & $\begin{array}{l}\text { Comité para Propagar el } \\
\text { Uso del Cemento Portland }\end{array}$ & $\begin{array}{l}\text { Federico Sánchez } \\
\text { Fogarty }\end{array}$ \\
\hline Arquitectura-México** & I938-I978 & Mario Pani & Mario Pani \\
\hline
\end{tabular}

* Antecedido por el Anuario de la SAM (1922-1923).

** Hasta 1946, el nombre de la publicación era Arquitectura. Selección de Arquitectura, Urbanismo y Decoración.

Abordaremos estos ejes analíticos desde la lógica propia y las características intrínsecas de una revista en cuanto medio de comunicación. Este tipo de publicación circula con facilidad: aparece periódicamente y puede llegar a abarcar espacios geográficos amplios, por lo que constituye una herramienta apta para hacer circular conceptos, ideas e imágenes nuevos (o modernos) incluso más allá de las fronteras nacionales. El carácter cosmopolita de una casa editorial se debía, en parte, a la práctica común de intercambiar textos e ilustraciones con revistas internacionales o publicar los reportajes de corresponsales que radicaban fuera del país. El aspecto visual y gráfico de la revista era fundamental para esta labor de diseminación transnacional del lenguaje moderno. En la época de nuestro estudio, la de entreguerras del siglo xx, nuevas tecnologías de reproducción hicieron posible que las publicaciones incluyeran imágenes de alta calidad y bajo costo en sus páginas. ${ }^{4}$ En las revistas mexicanas de arquitectura veremos cómo difundían la arquitectura moderna de otros países por medio de dichas reproducciones y cómo, a su vez, propa-

4. En el caso de Arquitectura-México, cuyos años de circulación rebasan esta temporalidad, nuestro análisis se limitará al periodo señalado. 
gaban la construcción mexicana en el extranjero. Efectivamente, la modernidad de una revista operaba antes que nada en su dimensión visual.

Al mismo tiempo, la revista obedecía por su naturaleza a un mercado local conformado por sus lectores, suscriptores, anunciantes y patrocinadores. Claro está, lo que más ataba a estas publicaciones a su "lugar" era su dependencia de los ingresos de las ventas y de los anuncios publicitarios y, en su caso, de la disposición de las instituciones patrocinadoras. A su vez, la revista "revisaba" el estado de la opinión pública de su entorno inmediato y procuraba influir en ella mediante manifiestos editoriales, artículos polémicos e imágenes. Las tres publicaciones analizadas destacan por la vehemencia con que defendían sus posturas programáticas (a favor de cierto lenguaje de construcción) y su afán proselitista (que involucraba la variedad de intereses que acabamos de mencionar).

De tal manera, postulamos que, por su forma de operar, la revista era un medio particularmente sensible tanto a las corrientes cosmopolitas internacionales como a las nacionalistas locales. Era una especie de mediador entre un mundo "universal" y un lugar específico. En este caso, las revistas mexicanas de arquitectura balanceaban sus lazos y mensajes modernistas cosmopolitas con el lugar en que circulaban: un México nacionalista y revolucionario que se encontraba a veces abierto y a veces cerrado a las corrientes extranjeras. 5

\section{El Arquitecto, "La Sección de Arquitectura" (Excélsior) y la SAM}

La revista El Arquitecto fue la voz editorial del gremio de arquitectos nacionales, la Sociedad de Arquitectos Mexicanos (SAM), y comenzó a circular a partir de 1922 como Anuario y como publicación mensual desde el año siguiente hasta I933. ${ }^{6}$ Junto con El Arquitecto circuló una publicación dedicada a divul-

5. Para un análisis de cómo la historiografía de la arquitectura ha abordado el tema de la recepción de corrientes internacionales por los arquitectos de América Latina, véase Georg Leidenberger, "Más allá de la 'apropiación': una revisión crítica de la historiografía de la arquitectura moderna de América Latina”, en Miruna Achim y Aimer Granados (coords.), Itinerarios e intercambios en la historia intelectual de México, México, Consejo Nacional para la Cultura y las Artes/Universidad Autónoma Metropolitana-Cuajimalpa, 20 o.

6. La primera revista de arquitectura en México fue El Arte y la Ciencia (I899-I9I I) y, dirigida por Nicolás Mariscal, también abarcó temas de ingeniería. Noelle, op. cit.; María de Lourdes Díaz Hernández, "Ideólogos de la arquitectura de los años veinte en México. Sección 
gar la profesión: "La Sección de Arquitectura", que apareció semanalmente en el periódico Excélsior. Fundada por Guillermo Zárraga en 1922, perduró hasta 193I. Igual que El Arquitecto, fue editada por la SAM (entre I925 y 1927) o por miembros prominentes de la misma (en un tiempo por el director de la SAM, Alfonso Pallares, y también por otros arquitectos asociados como Juan Galindo Pimentel, Bernardo Calderón y Caso y Bernabé León de la Barra).7

El Arquitecto fue principalmente una revista del y para el gremio. Vio la luz sólo tres años después de que se había establecido de nuevo la SAM, la cual fue fundada en $1905 .{ }^{8} \mathrm{El}$ indudable protagonista de la revista, Alfonso Pallares, fue director de la publicación a lo largo de su existencia y también autor de un gran número de textos. ${ }^{9}$ Dentro de sus funciones gremiales, $E l$ Arquitecto informó sobre los estatutos de la SAM, sus elecciones directivas, los calendarios de eventos — como, por ejemplo, la Primera Convención de Arquitectos Mexicanos en I93 I- y las graduaciones de los egresados de la Academia Nacional de Bellas Artes (desde 1929, Facultad de Arquitectura).

A su vez, la revista quiso alcanzar un público más amplio, sobre todo con el fin de encontrar clientes para la construcción. Ofrecía con cierta frecuencia un directorio de arquitectos de la ciudad de México. Publicó, como volumen separado, el Directorio de construcción en México, donde en más de 400 cuartillas se presentaron todo tipo de materiales de construcción junto con sus proveedores. El Directorio —editado por Pallares junto con Federico Storm, ex presidente de la Empresa de Ingeniería - se dirigió a "cualquier persona que tenga pensado construir una casa" en un "lenguaje claro y preciso [...] hacien-

de Arquitectura del periódico Excélsior", tesis de maestría, Universidad Nacional Autónoma de México-Facultad de Filosofía y Letras, 2003, p. 57; Carlos Ríos Garza (ed.), "Revista El Arte y la Ciencia México", Raices Digital, en Fuentes para la historia..., op. cit., núm. Iо, edición digital.

7. Díaz Hernández, op. cit., pp. 52 y 6I. A lo largo de nueve años se presentaron 2467 artículos en un apartado de tres páginas en la sección dominical de este diario capitalino.

8. Anteriormente, los arquitectos formaban parte de la Asociación de Ingenieros y Arquitectos, establecida en I868, en la cual los ingenieros dominaban numéricamente. Graciela María Guadalupe de Garay Arellano, "La profesionalización de la arquitectura en el Estado posrevolucionario mexicano: Mario Pani, un ejemplo de arquitecto moderno, I9II-I993", tesis de doctorado, México, Universidad Iberoamericana, 2009, p. 258.

9. Pallares llegó a influir notablemente en el contenido de la revista, dando lugar incluso a la autopromoción. Por ejemplo, usó una buena parte del número 7 (enero de 1926) para presentar su propuesta de remodelación del Zócalo, al incluir planos de gran formato plegables e impresos a color. 
do a un lado los tecnicismos y términos científicos" . ${ }^{\text {o }}$ Sin duda, este tipo de esfuerzos buscaba promover la construcción formal profesional ante el alza de demanda de vivienda en la década posrevolucionaria por parte de una creciente clase media capitalina. Encontrar clientes era sólo un aspecto dentro del más amplio intento de reforzar la legitimidad de la profesión de arquitectura, lo cual fue el propósito principal de la segunda publicación del gremio, "La Sección". Según su fundador, el arquitecto Zárraga, ésta tenía que "formar un vínculo con el lector" para mostrarle el quehacer de la profesión y de esta manera mejorar la estima del público por la misma. Así, decía Zárraga, la publicación serviría para "defender los fueros de la profesión". ${ }^{\text {I }}$

El tono defensivo del editor sugiere la precaria situación de la profesión a la postre de la guerra revolucionaria mexicana. No sólo en México, sino en el mundo occidental, la arquitectura había sufrido una paulatina pérdida de prestigio. En tiempos del ancien régime, los afortunados arquitectos reinaban prácticamente como los "segundos soberanos del Estado", siendo figuras clave de la proyección física y simbólica del Estado absolutista. Con las revoluciones modernas no sólo se veían forzados, igual que los pintores o los músicos, a encontrar trabajo en un "mercado", sino veían amenazada su legitimidad frente a la enorme competencia de los ingenieros, cuyo poderío técnico de construcción era más compatible con las ideologías positivistas cientificistas de los Estados decimonónicos. A lo largo del siglo XIX, fueron ellos quienes fijaron, en primera instancia, las infraestructuras de las naciones modernas. En el México decimonónico, los arquitectos sufrieron un doble desplazamiento: primero, igual que en Europa, tuvieron que ceder el protagonismo a los ingenieros (hecho ilustrado por la política de educación de Benito Juárez, en la que la formación del arquitecto, ahora denominado "arquitecto-ingeniero", fue integrada a la carrera de ingeniería), y, además, enfrentaron la fuerte competencia con los arquitectos extranjeros, quienes solían obtener contratos para las obras públicas importantes del porfiriato (como Adamo Boari para el Palacio de Bellas Artes). ${ }^{\mathrm{I}}$ En estas circunstancias, enfrentados con la reanudación de la construcción de la ciudad de México en los años veinte, los arquitectos vieron en las publicaciones periódicas una herramienta para recuperar su legitimidad ante la opinión pública.

Io. El Arquitecto, núm. 8, marzo-abril de 1926, s. p.

I I. Díaz Hernández, op. cit., pp. ix, 56 y 58.

I2. De Garay, op. cit., pp. 250-259. 
Ante esta tarea y en tiempos en que tocaban a la puerta las corrientes del movimiento moderno, ¿qué tipo de arquitectura promovían los editores de $E l$ Arquitecto y de "La Sección"? En las páginas de la primera publicación destaca la presencia de obras recientes de la ciudad de México, casi todas representativas de la corriente dominante de la época, el neocolonialismo. Por ejemplo, hubo un número dedicado a obras clave del protagonista de dicho estilo, Carlos Obregón Santacilia: la Escuela Nacional Preparatoria, el Grupo Escolar Benito Juárez y el edificio de la Secretaría de Relaciones Exteriores. Asimismo, se presentó el pabellón de México para la Exposición Iberoamericana de Sevilla de 1926, construido en estilo neomaya. ${ }^{\mathrm{I3}}$ En cambio, en las páginas de la revista brillan por su ausencia obras del movimiento moderno; no aparecen edificaciones de la tendencia racionalista ni del art déco. Aparentemente, ni siquiera las innovadoras obras de Villagrán García, como el Instituto de Higiene de Popotla (1924) y su posterior Sanatorio de Huipulco, Tlalpan (I929), fueron incluidas. ${ }^{\mathrm{I}}$ Sólo a partir de 1933 la revista se abrió a las nuevas corrientes, al mismo tiempo que el gremio cambió su actitud hacia ellas. ${ }^{\text {I5 }}$ Por ejemplo, en ocasión del fallecimiento del arquitecto Juan Legarreta, se publicó un número especial donde unos io miembros distinguidos de la SAM rindieron homenaje a este líder de una joven generación de colegas radicales y además se expusieron los croquis de sus casas mínimas para obreros; también aparecieron las escuelas racionalistas de Juan O`Gorman, otro protago-

I3. El Arquitecto, núm. 9, mayo-junio de I926. También hubo amplia cobertura de proyectos de restauración, como las obras del Castillo de Chapultepec y la ampliación del Palacio Nacional. Ibidem, junio de 1926.

I4. La resistencia de la revista hacia la construcción moderna se manifestaba también en una fuerte crítica a la Escuela Superior de Construcción (antecesora de la Escuela Superior de Ingeniería y Arquitectura del Instituto Politécnico Nacional), fundada en I932 con una orientación funcionalista y que fue vista como institución rival de la Facultad de Arquitectura de la unam. Rafael López Rangel, Orígenes de la arquitectura técnica en México, I920-I933. La Escuela Superior de Construcción, México, Universidad Autónoma Metropolitana-Xochimilco, 1984, p. 34. Sobre el carácter innovador de las obras de Villagrán García, véase Valerie Fraser, Building the New World: Studies in the Modern Architecture of Latin America, Nueva York, Verso, 200o, pp. 34-35.

I5. Georg Leidenberger, "Las 'pláticas' de los arquitectos de 1933 y el giro racionalista y social en el México posrevolucionario", en Carlos Illades y Georg Leidenberger (coords.), Polémicas en la historia intelectual mexicana, México, Consejo Nacional para la Cultura y las Artes/Universidad Autónoma Metropolitana-Cuajimalpa, 2008. 


\section{6 GEORG LEIDENBERGER}

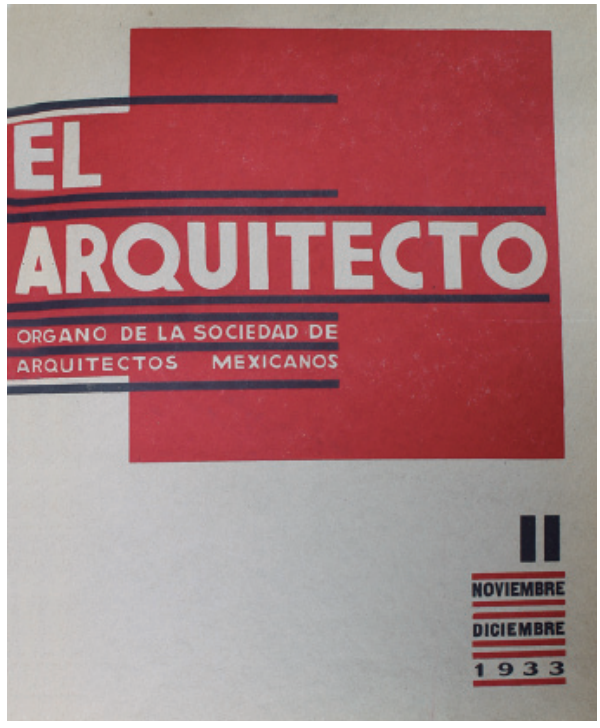

I. Portada de El Arquitecto, $2^{\mathrm{a}}$ etapa, vol. II, noviembre-diciembre de 1933 .

nista de los "funcionalistas". ${ }^{16}$ El sabor conservador de El Arquitecto también se hace notar en su aspecto visual, carente de cualquier tipo de innovación gráfica respecto a la letra o el formato. Solamente a partir de 1933 se introdujeron un nuevo tipo de letra y un layout más moderno, con espacios blancos que daban un aspecto austero y nítido. ${ }^{17} \mathrm{~A}$ veces, en un mismo número de la revista aparecían artículos con el nuevo formato junto con otros de forma tradicional (figs. I-4). ${ }^{\mathrm{I} 8}$

16. El Arquitecto, número "In memoriam", octubre de 1934; ibidem, $2^{\mathrm{a}}$ etapa, núm. 5 , enero de 1933 .

17. Pocos textos trataron temas fuera de la arquitectura propiamente: un artículo sobre la evolución urbanística de la capital y algunas muestras de la producción artística, por ejemplo, reproducciones a color de pinturas de Diego Rivera y objetos de artesanía mexicana. Ibidem, núm. 2, febrero de 1925. El director de la revista, Alfonso Pallares, coeditó junto con la periodista Anita Brenner un libro sobre este tema, Mexican Decorative Arts, del cual se reprodujeron algunas ilustraciones en la revista (mayo de 1927). En ocasiones se incluyeron breves reflexiones teóricas sobre la filosofía estética arquitectónica, el estatus de arte de la arquitectura nacional, así como sobre algunos tratados técnicos de Antonio Muńoz. El Arquitecto, núm. 2, febrero de 1925; núm. 9, mayo-junio de 1926.

I8. Ibidem, $2^{a}$ etapa, vol. II, noviembre-diciembre de 1933. 


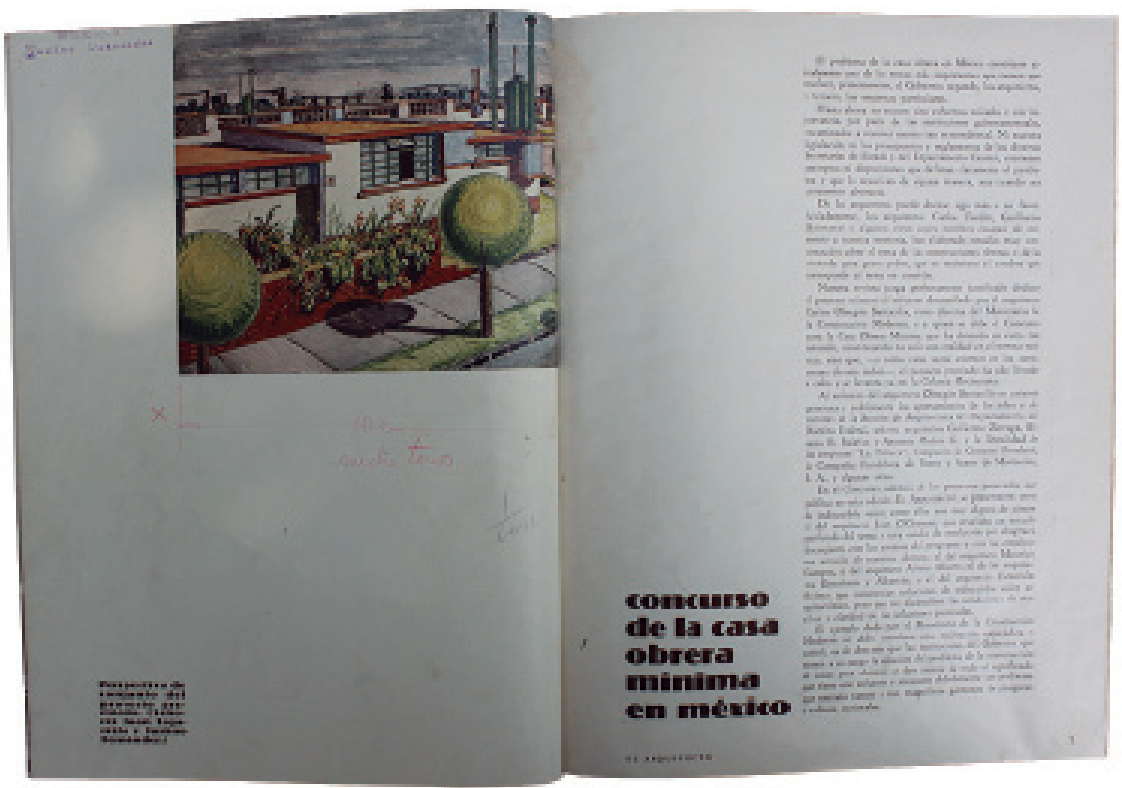

2. "Concurso de la casa obrero mínima”, El Arquitecto, 2a etapa, núm. 5, enero de I933, p. I.

El Arquitecto se centró en los aconteceres nacionales, dando relativamente poco espacio al mundo exterior. Los reportes sobre congresos se limitaban generalmente a los panamericanos, como el de 1923, en Santiago de Chile. ${ }^{19}$ Su sección de bibliografía incluía libros en otros idiomas (inglés, francés e italiano) y en ocasiones se citaban, o se tomaban, breves textos de revistas o libros extranjeros. ${ }^{20}$ Solamente bien entrados los años treinta se incluyeron textos extranjeros y de contenido moderno, como la publicación en español de un segmento del libro de Henry Russell Hitchcock The International Style. ${ }^{2 \mathrm{I}}$ Si bien los editores de la SAM, en particular los de "La Sección", no se cerraban hacia lo que ocurría en el extranjero, sí se manifestaron explícitamente

19. Ibidem, núm. 4, diciembre de I923. Sí se reportó el X Congreso Internacional de Arquitectos, realizado en 1923 en Bruselas.

20. En I926 se incluyó un listado de "Revistas recibidas", en el cual aparecían dos publicaciones de Uruguay, dos de Argentina y una de Cuba, así como una estadounidense, dos españolas, una italiana y una inglesa. Sin embargo, no se encuentran revistas vanguardistas como Moderne Bauformen o L'Esprit Nouveau.

21. El Arquitecto, 2 a etapa, vol. II, noviembre-diciembre de 1933. 


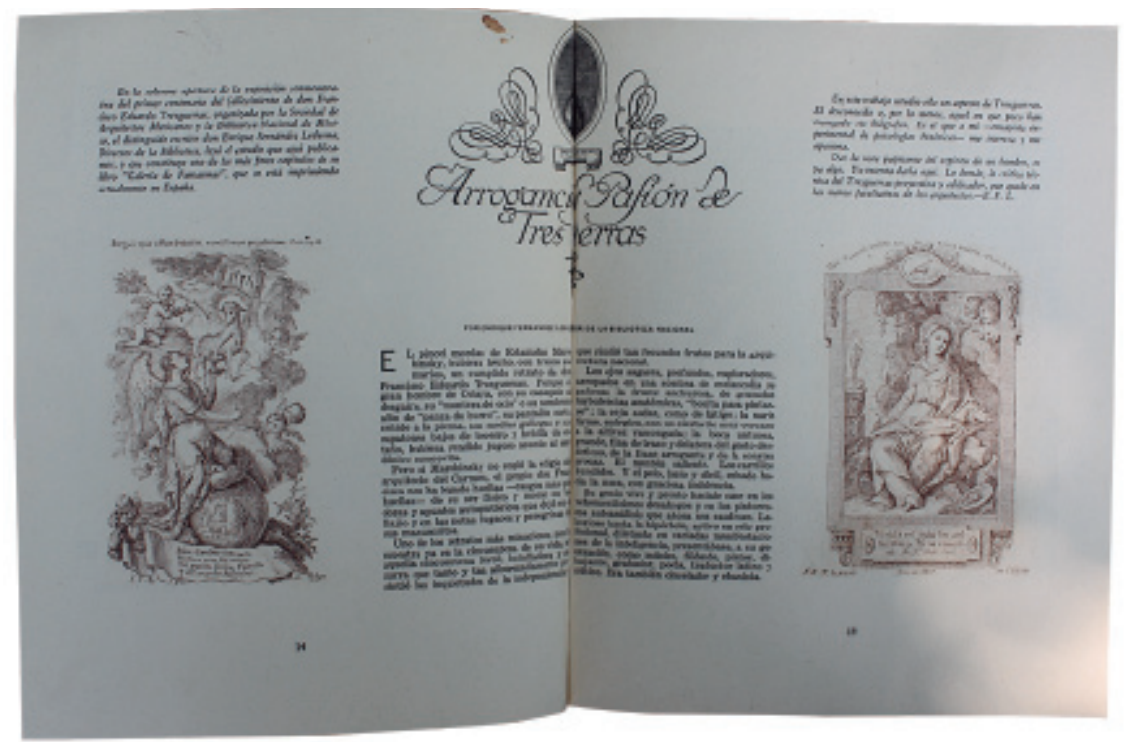

3. "Arrogancia y pasión de Tresguerras", El Arquitecto, $2^{a}$ etapa, vol. II, noviembre-diciembre de I933, pp. I4-I 5 .

en contra del peligro de una "imitación" que fuera incongruente con la realidad nacional. Insistían en que las tendencias "foráneas" solamente deberían adaptarse cuando sirvieran a las necesidades de la reconstrucción posrevolucionaria. ${ }^{22}$

Los editores de ambas publicaciones exigían que la labor arquitectónica mexicana respondiera a las tareas sociales de la posrevolución. En "La Sección", en particular, promovían la acción directa y pragmática del arquitecto en beneficio de las masas. En este sentido, insistían en que las viviendas estuvieran al alcance de la clase obrera. Para este fin, por ejemplo, publicaron tratados sobre la racionalización del diseño de las plantas de las viviendas. ${ }^{23}$ En un exhaustivo estudio sobre "La Sección", María de Lourdes Díaz Hernández señala este interés de la publicación en mejorar la habitabilidad de los sectores

22. Díaz Hernández, op. cit., pp. 83-88. En El Arquitecto, las revistas de donde se tomaban textos o citas provenían principalmente de la región de habla española, de países como Uruguay, Argentina y Cuba, así como España, con excepción de algunas referencias a publicaciones de Francia y Estados Unidos (por ejemplo, City Planning).

23. Ibidem, pp. 17 y 79 . 


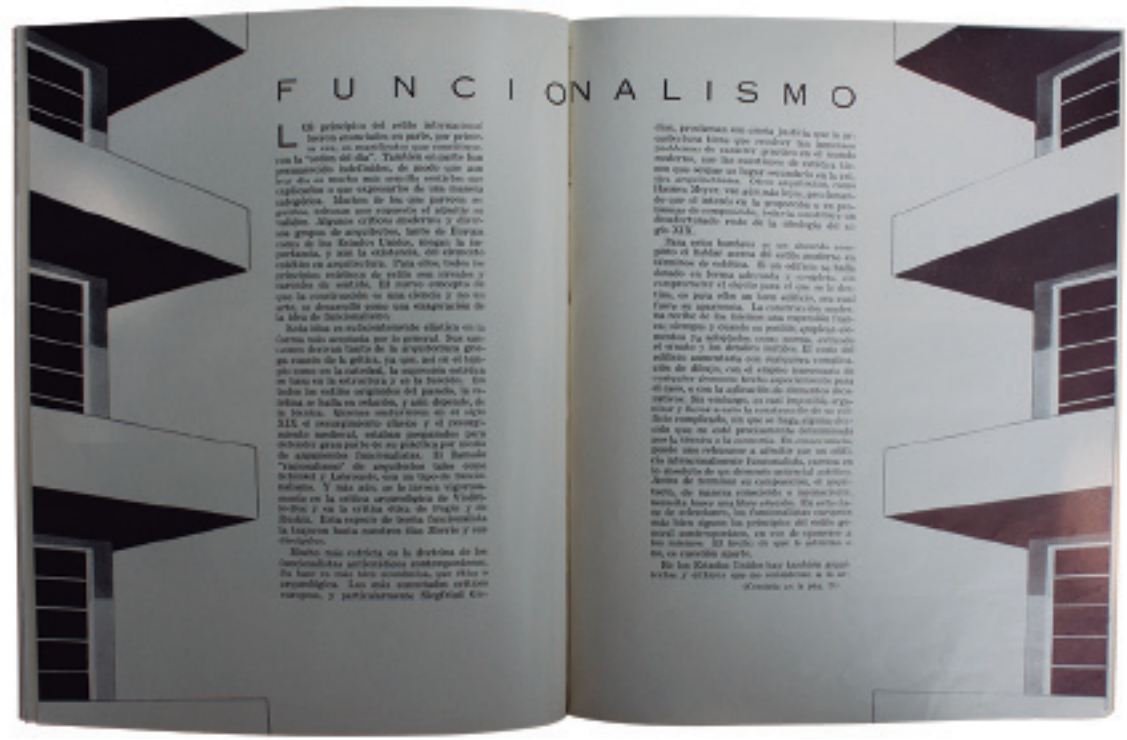

4. "Funcionalismo", $2^{\text {a }}$ etapa, vol. II, noviembre-diciembre de I933, pp. I 8 y I 9.

urbanos de las clases medias y populares. No obstante la falta de cobertura de las construcciones vanguardistas europeas, la autora insiste en la modernidad de la publicación, definida como "la consonancia [de las propuestas arquitectónicas] con las situaciones sociales y económicas del país”. ${ }^{24}$ Aun así, resulta extraño que el interés de los editores en una nueva habitabilidad para las masas no llevara a demostrar propuestas vanguardistas de vivienda económica, como la Weissenhofsiedlung (Mies van der Rohe, Stuttgart, Alemania, I927), por ejemplo. En El Arquitecto y "La Sección” destaca, pues, la ausencia de tendencias vanguardistas internacionales y nacionales, lo que sugiere que entre los editores (y la SAM) prevalecía una postura conservadora y cerrada especialmente hacia innovaciones del extranjero.

24. Ibidem, p. 70. Viendo el programa arquitectónico desde esta perspectiva y no de la estilística como tal, el modernismo arquitectónico, para Díaz Hernández, no significó una ruptura radical con las prácticas del porfiriato ni fue producto exclusivo de una nueva generación rebelde (centrada historiográficamente en Juan O'Gorman), sino más bien fue un trabajo acumulativo de varias generaciones de arquitectos que laboraban desde finales del siglo xIx. Esta continuidad se manifiesta, por ejemplo, en las preocupaciones higienistas de ambos periodos y generaciones. Véase Alberto J. Pani, La higiene en México, 1916, apud Díaz Hernández, op. cit. 
Las metas de estas publicaciones eran otras: primero, consolidar el campo profesional hacia adentro, por medio de reportajes sobre las obras y los personajes dominantes, así como los asuntos internos administrativos del gremio, $y$, segundo, dar mayor visibilidad, y por ende legitimidad, al campo ante un público capitalino más amplio, al cual había que convencer de que la construcción debería ser prerrogativa de profesionistas con competencia técnica y con una aguda conciencia de las exigencias culturales y sociales del momento histórico del país. Al respecto, El Arquitecto y sobre todo "La Sección” optaron por asociar la vigencia de su programa arquitectónico con el discurso revolucionario y nacionalista, ignorando casi por completo el movimiento de arquitectura moderno como tal. Por razones desconocidas, El Arquitecto y "La Sección" dejaron de circular desde inicios de los años treinta (I933 y I93 I, respectivamente), dejando al gremio de arquitectos sin una publicación periodística, justo cuando el movimiento moderno entraba con pleno vigor al ámbito capitalino y nacional. ${ }^{25}$

\section{Cemento y Tolteca y el Comité para Propagar el Uso del Cemento Portland}

La primera revista de vanguardia del campo de la arquitectura mexicana surgiría desde otro rincón, uno quizá poco esperado por la elite profesional: la industria del cemento y su Comité para Propagar el Uso del Cemento Portland. ${ }^{26}$ Sus revistas Cemento — que circuló entre 1925 y 1930- y Tolteca —vigente entre 1929 y 1932 - fueron sumamente innovadoras en contenido y forma. A su vez, lograron obtener una presencia amplia tanto en el escenario nacional como en las redes de arquitectos y revistas del extranjero. Finan-

25. Entre 1938 y 1939 circuló la revista Arquitectura y Decoración, editada por Luis Cañedo Gerard, uno de los colaboradores de El Arquitecto. Sin embargo, no era una publicación asociada directamente a la sam. Agradezco esta aclaración a Carlos Ríos Garza.

26. Estudios recientes han destacado el papel de la revista en la diseminación visual fotográfica de la arquitectura moderna en México. Véase James Oles, "La nueva fotografía y cemento Tolteca: una alianza utópica”, en María Casanova (coord.), Mexicana. Fotografía moderna en México, 1923-I940, Valencia, IVAM, I998; y Deborah Dorotinsky Alperstein, "Federico Sánchez Fogarty: el concreto y la fotografía de arquitectura en I933”, en Concepción J. Vargas Sánchez y Enrique Ayala Alonso (coords.), Seminario Internacional. Arquitectura y Ciudad. Métodos historiográficos: análisis de fuentes gráficas. Memorias, Universidad Autónoma Metropolitana, http://unam.academia.edu/DeborahDorotinsky/Papers/668527/Federico_Sanchez_Fogarty_cemento_y_fotografia, consultado el 20 de marzo de 2012. 
ciadas por el sector privado, Cemento y Tolteca lograron combinar su función de órgano publicitario y comercial — la promoción del uso del cemento en la construcción - con la primera diseminación masiva de la arquitectura moderna en México. En las páginas de la revista, el lector aborda la modernidad a través de su materia prima, el cemento. ${ }^{27}$ Igual que en El Arquitecto, un solo hombre fue la figura central en la edición de Cemento y Tolteca: Federico Sánchez Fogarty, quien las dirigió y se encargó de la publicidad del Comité Portland que fundaron varias empresas de cemento dos años antes de la aparición de Cemento. ${ }^{28}$ También fue autor de la mayoría de los artículos, los cuales firmaba con alguno de sus seudónimos, ya fuera "OzY" (de "FedericO SáncheZ FogartY") o "Derisanty" (de FeDERIco SÁNchez FogarTY). ${ }^{29}$

Estas dos revistas perseguían un propósito sumamente "concreto": la promoción del mismo en una época en que este reciente producto de construcción era visto con desdén tanto por los arquitectos como por los usuarios. Muchos arquitectos sí lo empleaban en las construcciones neocoloniales pero solían disfrazarlo o recubrirlo con otros materiales para que pareciera piedra de arena, por ejemplo. ${ }^{30} \mathrm{El}$ secretario de Educación y gran promotor del neocolonialismo José Vasconcelos detestaba tanto ese material que inicialmente se opuso a emplearlo para edificios como el Estadio Nacional, céle-

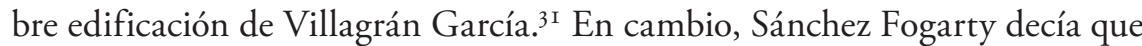
el cemento era el elemento emblemático de la construcción de vanguardia y que había que exhibirlo abiertamente. ${ }^{32}$ En las páginas de Cemento aparecía cualquier nueva edificación hecha con concreto, ilustrada ampliamente con croquis, dibujos y fotografías. Al principio estos edificios eran de tipo neocolonial o californiano, pero a partir de 1927 Sánchez Fogarty difundió las

27. El cemento no es precisamente una materia prima sino un producto manufacturado, que resulta de un complejo proceso de hornear y luego moler caliza y arcilla. El cemento es un ingrediente - junto con grava, arena y agua - del concreto, material de construcción primordial. http://es.wikipedia.org/wiki/cemento.

28. Cámara Nacional del Cemento, http://www.canacem.org.mx/la_camara_historia. htm; consultado el 2 de marzo de 20I2. El Comité Portland fue el antecesor de la actual Cámara Nacional del Cemento. Idem.

29. Rubén Gallo, Mexican Modernity: The Avant-garde and the Technological Revolution, Cambridge, Miт Press, 2005, p. I84.

30. Díaz Hernández, op. cit., pp. I5-16; Gallo, op. cit., p. I80. Según Gallo, la promoción del cemento que emprendió Fogarty fue "un proceso lento, arduo y tortuoso". Ibidem, p. I7I.

3I. Gallo, op. cit., pp. 203-204.

32. Ibidem, p. $\mathbf{I} 72$. 
obras modernas europeas. ${ }^{33} \mathrm{Si}$ el lector mexicano de entonces quería enterarse de las construcciones de Le Corbusier, de J.J.P. Oud o las viviendas Weissenhof, las podía encontrar en Cemento y Tolteca, y solamente en estas revistas. En ellas uno encontraba también los primeros hitos de la construcción moderna mexicana, como el Instituto de Higiene de Popotla (Villagrán García, I924), las propuestas de casas económicas (y parcialmente prefabricadas) del ingeniero F. Loría (1927), la casa para Manuel Gómez Morín de Carlos Obregón Santacilia (I93I) y las casas mínimas para obreros de Juan Legarreta (I93I); de todas estas obras Tolteca informó años antes que El Arquitecto. ${ }^{34}$

Disfrutando de un amplio tiraje de 10 ooo ejemplares, ${ }^{35}$ Cemento y especialmente su sucesora Tolteca — que en su mismo nombre pasó de la promoción del material a la de la marca- combinaron la tarea de publicitar el cemento con la divulgación de la arquitectura moderna. Sobre todo la revista Tolteca era abiertamente publicitaria, pues incluía en todos sus artículos y exposiciones fotográficas el logotipo de la empresa junto con la frase: "En todas estas obras se empleó Cemento Tolteca". Sin embargo, esta abierta comercialización de un producto se insertaba en una visión coherente del mundo moderno: una Weltanschauung en la que se integraban dos facetas de una nueva época: un material y una idea, es decir, el cemento y la modernidad. El mensaje de Sánchez Fogarty y de su revista giraba alrededor de la ubicuidad del cemento: aparecía y dominaba la construcción de casas, edificios, monumentos, bancas y faroles de parques, abajo y por encima de calles, en las presas, autopistas y aeropuertos y como tal figuraba literal y metafóricamente como "el material en que se fundirá el espíritu de nuestro siglo”. Lo que a primera vista pudiera parecer una hipérbole (o una vil imitación de la visión espiritual vasconceliana), de hecho era congruente con la filosofía de la revista y de su editor, según la cual el gran avance que significaba la arquitectura moderna se fundaba en la fusión entre una materia y una idea (una construcción austera, racional, nítida). De tal manera, en la revista, junto con la promoción del cemento, se justificaba la validez de la modernidad: "los rascacielos son el resultado de un sistema mecanizado de la producción. Pilares romanos no pueden enfrentar, y mucho menos simbolizar, las

33. Oles, op. cit., p. I4I.

34. Tolteca, núm. 20, agosto de I93I, p. 28I; ibidem, núm. 21, enero de I932, p. 300.

35. Cámara Nacional del Cemento, www.canacem.org.mx/la_camara_historia.htm; consultado el 2 de marzo de 2012. 
fuerzas conflictivas que reinan en nuestros edificios dinámicos", decía Sánchez Fogarty. ${ }^{36}$

El vanguardismo de las revistas del cemento se veía reflejado en su aspecto gráfico: portadas a múltiples colores con elementos cubistas - muchas de ellas realizadas por el pintor Jorge González Camarena-, formas tomadas del art déco, una tipografía moderna y una estética austera lograda por el uso de amplios espacios blancos. Destacan también las numerosas fotografías de edificios tomadas por artistas como Manuel Álvarez Bravo, Agustín Jiménez y Paul Strand. Como señala Deborah Dorotinsky, la fotografía resultó clave para la promoción de la arquitectura moderna en México, ya que existía una "relación recíproca" entre ambos medios que promovía "la maduración de un modo vanguardista de ver" ${ }^{37}$ Ciertamente, las revistas de Sánchez Fogarty contribuyeron a esta forma de ver (figs. $5 \mathrm{a}$, $5 \mathrm{~b}$ y $5 \mathrm{c}$ ). ${ }^{38}$

De acuerdo con su finalidad publicitaria, las dos revistas buscaron obtener una distribución amplia y una relación directa con su público lector. Cemento empezó en 1925 con una circulación mensual de 8000 ejemplares — que aumentó en un año a I 2000 - gratuitos y dirigidos a "gobernantes, sacerdotes, industriales, agricultores, comerciantes, profesionales en general, constructores y propietarios o futuros propietarios". ${ }^{39}$ El estilo y la variedad de los textos —que incluían caricaturas, por ejemplo- estaban pensados para atraer a esta gran gama de lectores. Además, los editores involucraron a los lectores en la creación de la revista, al pedirles que enviaran fotografías de nuevas casas llamativas o al ofrecerles ayuda en cuestiones técnicas de la construcción.

36. Federico Sánchez Fogarty, "The Architect as Contractor in Mexico", en Esther Born, The New Architecture in Mexico, Nueva York, The Architectural Record, William Morrow \& Co., 1937, p. I3 (la traducción es mía). El autor describía el rascacielos como una "estructura cuasi-orgánica repleta de una vida de alambres electrificados, aire acondicionado y agua corriente". Idem.

37. Dorotinsky, op. cit., p. 216; Casanova (coord.), op. cit., pp. II4-II6, I24-I25 y 20I; Gallo, op. cit., pp. I87-I88. Por ejemplo, Cemento, núm. 3I, septiembre de I929.

38. Sánchez Fogarty seguía empleando a estos y otros fotógrafos para la difusión de la arquitectura moderna y el cemento en otras revistas que aparecieron después de las aquí tratadas, como Revista de Revistas e Imagen. Dorotinsky, op. cit., p. 207. Lo mismo sucedió con Arquitectura-México, revista que trataremos en la siguiente sección, en la cual apareció mensualmente, durante las décadas de 1930 y 1940, un anuncio de Cemento Tolteca con una fotografía de Álvarez Bravo (ilustración diferente a la ganadora del concurso).

39. Cemento, núms. 8 y 9, agosto-septiembre de I925, p. 3. 

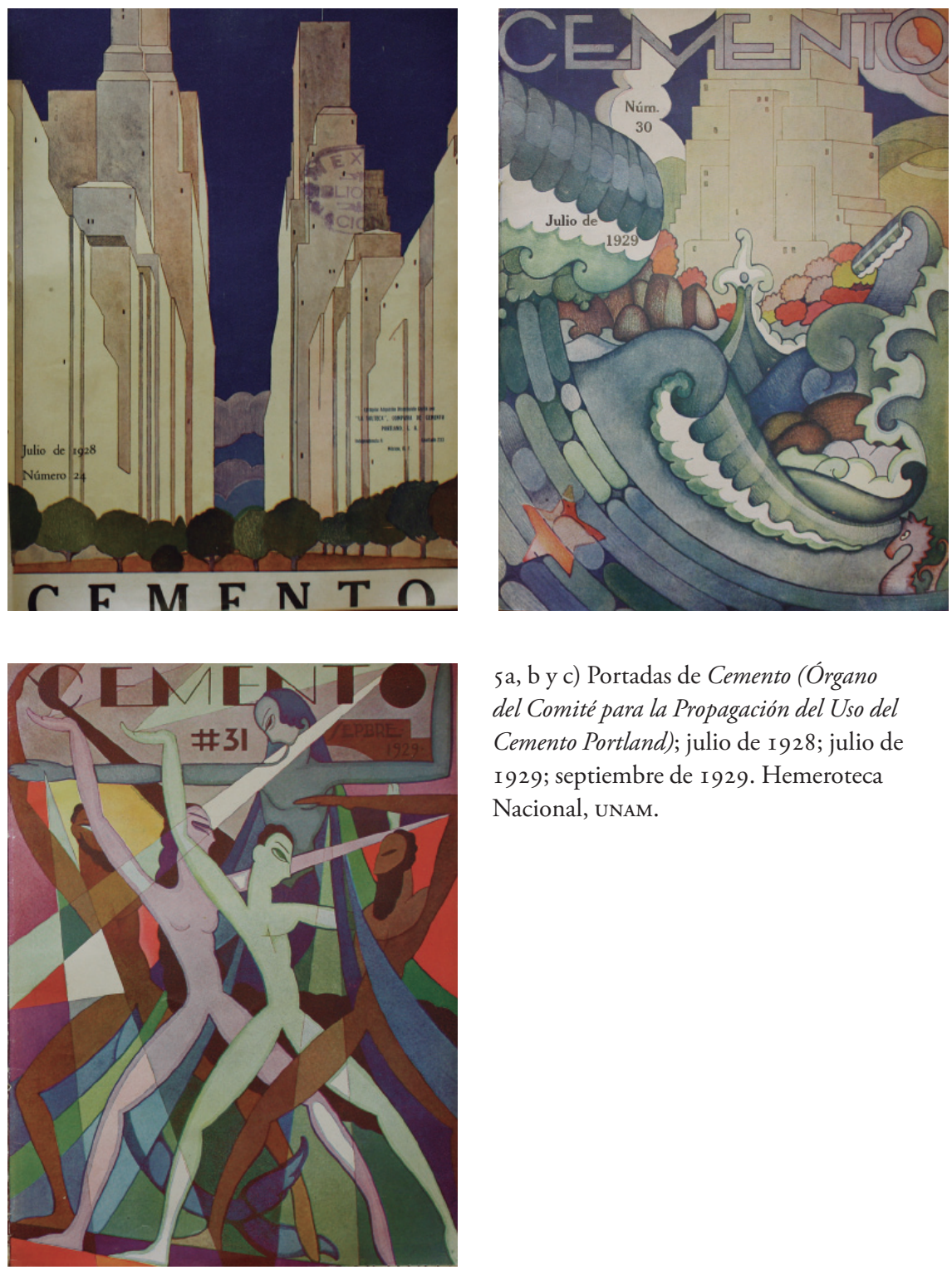

5a, b y c) Portadas de Cemento (Órgano del Comité para la Propagación del Uso del Cemento Portland); julio de I928; julio de I929; septiembre de I929. Hemeroteca Nacional, UNAM. 
Su meta principal iba más allá de la promoción de la construcción moderna con cemento: querían "crear la opinión pública". ${ }^{40}$ Según la periodista Anita Brenner, Sánchez Fogarty "invadió la ciudad con concursos artísticos, revistas, ponencias y todo tipo de propaganda dinámica, inteligente y pro-moderna". ${ }^{4}$ En lo que resultó ser un publicity stunt sin precedentes, Tolteca convocó en su número de agosto de I93 I a un concurso de obras artísticas cuyo tema debía abarcar la nueva fábrica de Cemento Tolteca recién construida en Lomas de Becerra (colonia Mixcoac). ${ }^{42}$ Los editores contaron con la participación del diario Excélsior, el respaldo de la Facultad Nacional de Ingeniería y el visto bueno del pintor Diego Rivera, quien aclamó la belleza y funcionalidad de la nueva planta. Rivera, el arquitecto Manuel Ortiz Monasterio y Sánchez Fogarty integraron el jurado calificador y después de unos meses anunciaron a los ganadores entre los más de 500 candidatos: Manuel Álvarez Bravo, en el rubro de fotografía, y el arquitecto Juan O’Gorman, en pintura. ${ }^{43}$ Durante las dos primeras semanas de diciembre se expusieron las obras participantes en el Teatro Nacional de México, que fue visitado, según Tolteca, por 50000 personas. ${ }^{44}$ El llamado "Concurso Cemento Tolteca" no sólo fue "la más ambiciosa, más exitosa y más espectacular campaña publicitaria de cemento en México", 45 sino también una forma de incluir dicho material dentro de una amplia cultura vanguardista que abarcaba el arte, la fotografía y la arquitectura. ${ }^{46}$ Para James Oles, el certamen, más que una campaña publicitaria, fue "uno de los primeros ejemplos de patronazgo de las artes en México". ${ }^{47}$ Debido a este tipo

40. Ibidem, p. 3 .

4I. Anita Brenner, Your Mexican Holiday, I937, citado en Born, op.cit., p. Io.

42. Tolteca, núm. 20, agosto de I93 I. Con este edificio, la empresa extendió la producción desde su sede principal en Tula, Hidalgo, a la ciudad de México.

43. En el concurso participaron los pintores O’Gorman, Rufino Tamayo, Jorge González Camarena y Carlos Tejeda, entre otros, y los fotógrafos Manuel Álvarez Bravo, Lola Álvarez Bravo y Agustín Jiménez. La fotografía ganadora de Álvarez Bravo, llamada "Tríptico Cemento 2", muestra las fases de elaboración y utilización del cemento y exalta una estructura (funcionalista) que solamente era realizable con dicho material. Gallo, op. cit., pp. I87-r9r; Oles, op. cit., p. I39; Dorotinsky, op. cit., p. 206.

44. Oles, op. cit., p. I39.

45. Gallo, op. cit., p. I87.

46. Masha Salazkina, In Excess. Sergei Eisenstein's Mexico, University of Chicago Press, 2009, pp. I63-I67. Como se señala en la nota I7, también la revista El Arquitecto buscó vincular el arte de la construcción con otros campos culturales, pero en mucho menor medida.

47. Oles, op. cit., p. I39. 
de acciones publicitarias, el movimiento moderno de arquitectura se difundió entre un amplio espectro de lectores mexicanos. Aunque con ello "la gran batalla entre "lo cúbico y lo tradicional"” no era "historia acabada"; como afirmaba una contemporánea, lo "cúbico" se volvió una forma de construcción que, de allí en adelante, sería imposible ignorar. ${ }^{48}$

La modernidad de Cemento y Tolteca se manifestó en los extensos vínculos que tenían las editoriales con revistas e instituciones internacionales. Para sus exposés de obras extranjeras, los editores retomaron las ilustraciones (croquis y fotografías) de revistas estadounidenses, como Architectural Record, American Builder y The American Architect, todas ellas revistas de amplia difusión en los Estados Unidos que cubrían no sólo los avances constructivos de ese país sino también los de Europa. ${ }^{49}$ Pero Tolteca también reprodujo artículos de revistas vanguardistas europeas como Moderne Bauformen, Architecture d'Aujourd'hui y Le Génie Civily, muy ocasionalmente, de publicaciones de países latinoamericanos como Arquitectura de Uruguay y otra no nombrada de Venezuela. Los editores asumían abiertamente la práctica de reproducir textos de otras revistas; por ejemplo, en la introducción de un artículo sobre el arquitecto alemán Hans Poelzig que habían tomado del American Architect, afirman: "nosotros [somos]... simples condensadores en realidad del artículo de Poelzing [sic]".$^{\circ}$ Los contactos de Cemento y Tolteca con la industria del cemento les facilitaron el acceso a las publicaciones estadounidenses, como lo indican las frecuentes citas de la revista homónima Cement.

Ambas revistas exhibieron este cosmopolitismo en tiempos en que predominaba en México un agudo nacionalismo, por lo que los editores de Cemento veían la necesidad de aclarar su postura al respecto. En una declaración de propósitos de enero de 1930, en ocasión del quinto año de circulación de la revista, comentaron lo siguiente:

Queremos mostrar los últimos movimientos arquitectónicos, mencionando e ilustrando las importantes y bellísimas obras ejecutadas en el extranjero [...] A esta razón se debe el que con tanta frecuencia aparezcan en nuestras páginas artículos y grabados de

48. Gallo, op. cit., pp. I90-I9I; Dorotinsky, op. cit., p. 206. Sobre el concurso, véase también Justino Fernández, "The New Architecture in Mexico", en Born, op. cit., p. I7.

49. Margret Kentgens-Craig, The Bauhaus in America. First Contacts 1919-1936, Cambridge, MIT Press, 200I, pp. 52-60.

50. Cemento, núms. Io y I I, octubre y noviembre de 1925 (las cursivas son mías), s. p. 
obras americanas, francesas, alemanas, etc., etc., y no al deseo de que en México se imiten servilmente, como han llegado a creer erróneamente algunos lectores. ${ }^{5 \mathrm{I}}$

Es decir, los editores justificaron su apertura hacia otros países con su misión de divulgación, ya que su propósito declarado era "darles ideas y sugestiones" a aquellas personas que no tuvieran suficientes recursos para recibir "esta clase de informaciones por otros conductos", y que de esta manera, eso sí, podrían realizar "sus proyectos de obras mexicanas". 52 En las primeras décadas posrevolucionarias, parecía que la apertura hacia el exterior sólo se justificaba con la utilidad que ésta pudiera tener para la causa nacional. Aun así, la campaña promodernista de Sánchez Fogarty fue severamente criticada como obra publicitaria de una empresa extranjera — el capital de Cemento Tolteca era de origen inglés - que intentaba importar una corriente imperialista. ${ }^{53}$ En todo caso, aplaudidas o reprochadas, las publicaciones de la industria del cemento abrieron una enorme brecha para que el ámbito cultural nacional se afrontara con las corrientes modernas internacionales.

Es más, estas revistas emprendieron, quizá por primera vez, la activa promoción de la arquitectura moderna mexicana en el extranjero, especialmente en los Estados Unidos. Varios autores de este país empezaron a informar sobre la construcción mexicana gracias a la labor de Sánchez Fogarty. En 1932, en su guía turística Your Mexican Holiday, Brenner informó sobre la proliferación de casas funcionalistas en México y sobre el papel de Sánchez Fogarty en promover el estilo moderno en este país; cinco años después apareció el libro The New Architecture in Mexico, de Esther Born, publicado por la principal revista estadounidense de arquitectura, Architectural Record.54

51. Cemento, núm. 33, enero de I930, p. 6

52. Idem.

53. Beach Riley, "Social Progress and the New Architecture", en Born, op. cit., p. I9 (la traducción es mía). Para Riley esta crítica no era válida, ya que, según él, la arquitectura funcionalista en México era, "en esencia, un asunto nativo mexicano". Idem. Véase también Dorotinsky, op. cit., pp. 2I I-2I2.

54. Born, op. cit.; Noelle, "La arquitectura mexicana", op. cit., p. 52. Luego, en I947, retomando el trabajo pionero de Born, Trent Elwood Sanford escribió The Story of Architecture in Mexico (Nueva York, Norton) al que siguió el libro de 1952 de I.E. Myers, Mexico's Modern Architecture (Nueva York, Architectural Book Publishing). Véase también Edward R. Burian, "Introducción", en Edward R. Burian (ed.), La modernidad en la arquitectura en México, Barcelona, Gustavo Gili, I998.

Más o menos una década después, la revista Espacios, que publicaron entre 1948 y I959 los 
Si reflexionamos más a fondo, lo que a primera vista podría parecer una limitante - el hecho de unas revistas con pretensiones culturales, financiadas y organizadas por una empresa privada y directamente interesadas en la venta de una materia prima - resulta ser un importante logro. Mientras que una publicación como El Arquitecto quedó ligada a la actitud cautelosa y conservadora del gremio, estas revistas, por su asociación con la iniciativa privada y el mercado de ventas, tuvieron una disposición más abierta hacia las nuevas tendencias arquitectónicas. Sin embargo, igual que la revista de la SAM, Cemento y Tolteca dejaron de circular a inicios de la década de los ańos treinta, por lo que tuvieron que transcurrir varios años hasta que otra revista se encargara de diseminar la arquitectura moderna nacional e internacional.

\section{Arquitectura-México y los inicios de la "empresa" Mario Pani}

Fue Arquitectura. Selección de Arquitectura, Urbanismo y Decoración, dirigida por Mario Pani, la revista que desde 1938 se dedicaría nuevamente a la tarea de la diseminación del movimiento moderno de arquitectura en México. Destaca, por lo menos para el periodo examinado de los años treinta y cuarenta, la manera abierta y pluralista con que los editores se acercaron a la construcción moderna. Con la ventaja de que las fuertes polémicas de inicios de los años treinta ya habían quedado atrás, la publicación de Pani logró exhibir la variada y contrastante gama de obras e ideas de la modernidad arquitectónica. A su vez, este acercamiento objetivo y pragmático a las tendencias modernistas no estaba desprovisto de compromisos institucionales propios; solamente que en este caso los intereses giraban alrededor de la persona - y cada vez más institución motu proprio- de Pani.

La revista asumió una mirada fresca y abierta hacia los acontecimientos de la arquitectura moderna internacional. En una declaración editorial solemne, en el número I (diciembre de 1938), Mario Pani señaló que el propósito de la revista era "documentar" las más importantes obras de arquitectura, urbanis-

arquitectos Guillermo Rossell de la Lama, Lorenzo Carrasco y Manuel Larrosa, siguió la pauta de Cemento de promover la arquitectura moderna mexicana en el extranjero. Por ejemplo, en i955 Rossell de la Lama colgó carteles en las calles y plazas de París con el manifiesto de la revista, en francés. Por este medio directo, los profesionistas mexicanos hicieron visibles sus ideas sobre la modernidad en el gran centro de la vanguardia moderna que era París en ese entonces. Espacios, núm. 28, noviembre-diciembre de 1955. 
mo y decoración; no se trataba de documentar cualquier tipo de innovación, sino sólo los que presentaran tendencias modernistas. ${ }^{55}$ Durante los primeros años de su existencia, la publicación se concretaba a reportar los sucesos constructivos de fuera de México, de "la Ciudad del Cabo [...] a Shanghai". ${ }^{6}$ Asimismo se dedicaba a difundir la obra de arquitectos europeos que llegaban a México, como Max Cetto, colaborador de la "escuela de Frankfurt" de Ernst May, y Hannes Meyer, director de la Bauhaus. ${ }^{57}$ El cosmopolitismo de la publicación también se hacía evidente en las frecuentes referencias a, y textos tomados prestados de, las revistas europeas como Moderne Bauformen y L'Architecture d'Aujourd' hui..$^{8}$ La revista contaba además con un buen número de corresponsales que transmitían las nuevas tendencias del mundo. Desde Europa escribía frecuentemente el arquitecto ruso y colega estudiante de Pani en París, Vladimir Kaspé, quien buscaba forjar una "feliz alianza entre los dos mundos, el europeo del arte y el americano de la innovación".59 Desde Estados Unidos informaba el corresponsal Kenneth Day y desde "América del Sur", Manuel Chacón. ${ }^{60}$

Sin dejar de lado dicha apertura internacional, en pocos años la revista asumió un enfoque más nacionalista, aumentando su cobertura del escenario arquitectónico local, hecho que se reflejó al cambiar de nombre a Arquitectura-México a partir de 1946. Se comenzaron a exponer las obras públicas primordiales del entorno nacional y capitalino, como la Ciudad Universitaria (1950-1952), la Secretaría de Comunicaciones y Obras Públicas (1954) y los conjuntos habitacionales Miguel Alemán, Benito Juárez y Santa Fe —construidos todos por el equipo de Pani-, entre otros. Los editores dirigieron la atención explícitamente a fomentar "nuestro Urbanismo y nuestra Arquitectura", que, según ellos, se encontraban a una "escala pigmea” en comparación con otros países. ${ }^{61}$

55. Arquitectura, núm. I, diciembre de 1938, pp. 3-4.

56. Ibidem, p. 3.

57. Arquitectura, núm. 3, julio de I939, pp. 54-55.

58. Aparecen algunas referencias a ciertas revistas de América Latina, incluyendo un homenaje a la ya mencionada revista uruguaya Arquitectura por sus 25 ańos de edad. "Arquerías", Arquitectura, núm. 6, julio de I940, p. 55.

59. En 1942 Kaspé llegó a México, donde asumió el puesto de Jefe de Redacción de la revista. Ibidem, p. 58 .

60. Arquitectura, núm. 7, mayo de I94I, p. I, y núm. I2, abril de I943, p. 65.

6I. En este caso se refirieron a Uruguay, donde en ese momento se celebraba el Congreso Panamericano de Arquitectos. Dicho país contaba con una revista de arquitectura de larga 
La revista quería acercar a los lectores las tendencias modernistas tanto internacionales como nacionales, sin caer, por un lado, en los faccionalismos que operaban dentro del gremio del país - los cuales se manifestaron en su momento en El Arquitecto - o en el proselitismo publicitario de las revistas del Comité del Cemento Portland, por el otro. Efectivamente, la nueva publicación podía respaldar este propósito neutral u objetivo con el hecho de que no estaba afiliada ni a un gremio ni, aparentemente, a una empresa de construcción, y también con el hecho de que su director era un new kid on the block en el ambiente de la construcción nacional, que había regresado a México a la joven edad de 23 años, luego de estudiar en la École des Beaux-Arts de París. Como señaló Pani en la declaración inaugural de la revista, al exponer la arquitectura moderna no pretendía "señalar un camino [o] imponer una tendencia" ${ }^{62}$ A dicha calidad de apertura y objetividad también se le señala en la historiografía como característica de la publicación. Por ejemplo, Louise Noelle (que entre 1976 y 1980 colaboró como editora de la publicación) subraya el carácter apolítico, apartidista y ecléctico de la misma que estaba dedicada a difundir la "buena Arquitectura" y que constituyó un "eco de los valores y el desarrollo de la disciplina arquitectónica". ${ }^{63}$

Efectivamente, en Arquitectura-México prevalecía una pluralidad de enfoques sobre la modernidad arquitectónica, que abarcaba los dos campos que se encontraban en eterna polémica entre sí: los “esteticistas" y los “radicales". Los apuntes teóricos de Villagrán García, que se publicaron de forma seriada en Arquitectura entre 1939 y I940, expusieron la primera postura. Al promover un funcionalismo abierto a elementos artísticos e incluso espirituales, Villagrán García quiso aunar armónicamente las exigencias de lo útil con la vida espiritual del hombre. ${ }^{64}$ Además, su postura era favorable a la historia, ya que buscaba reconciliar lo moderno con lo clásico, por ejemplo al exigir que se incorporaran la amplitud y la claridad de la composición romana antigua a las

trayectoria y con un presidente de la república arquitecto. Arquitectura, núm. 6, julio de I940.

62. Arquitectura, núm. I, diciembre de 1938.

63. Louise Noelle, "Estudio introductorio", op. cit., pp. I9 y 27; "La arquitectura y el urbanismo de Mario Pani. Creatividad y compromiso", en Burian, La modernidad, op. cit., p. I9I. Asimismo, Xavier Moyssén presenta la publicación de Pani como un "farol de la libertad de expresión" en un contexto en el que prevalecía el dogmatismo respecto a lo que se marcaba como la línea correcta del arte nacional. Citado en De Garay, op. cit., p. 292.

64. Leidenberger, "Las 'pláticas", op. cit., pp. I96-200. 
construcciones actuales. ${ }^{65}$ Había lugar en la revista para criticar al oponente; Villagrán García atacó el desenfrenado radicalismo de sus colegas funcionalistas, mientras que Manuel Chacón aprovechó su columna "Arquerías" para quejarse del espantoso "nudismo integral" reinante en muchas construcciones contemporáneas mexicanas y para pedir a sus colegas una mayor sensibilidad artística. Aunque en las páginas de la revista dominaba esta visión esteticista del movimiento moderno, también había lugar para el punto de vista funcionalista radical. Por ejemplo, Pani abrió su revista a Hannes Meyer, no obstante que el arquitecto suizo, entonces residente en México, era famoso por sus posturas antiesteticistas y socialistas (y, además, resultó ser una figura controvertida en el ámbito profesional de México). ${ }^{66}$ De esta manera, en las páginas de la revista se veían puntos de vista encontrados. En I94I-I942, Meyer publicó en Arquitectura un laudatorio reportaje sobre la arquitectura de la Unión de Repúblicas Socialistas Soviéticas (donde había trabajado antes de llegar a México), mientras que Chacón redactó una visión crítica de la situación en aquel Estado. ${ }^{67}$

65. Villagrán García, "Apuntes para un estudio", Arquitectura, núm. 3, julio de 1939; Arquitectura, núm. 6, julio de 1940. Villagrán expuso un tratado de arquitectura del francés Leonce Reynaud de I875, traducido por él mismo, que afirmaba el "ritmo histórico de las ideas directrices" de la arquitectura contemporánea. Arquitectura, núm. Io, julio de 1942, pp. 24-32; "Dos proyectos franceses recientes", ibidem, pp. 43-48, especialmente la p. 43.

66. Meyer fue invitado a México a dirigir el recién fundado Instituto de Urbanismo y Planificación del IPN. Sin embargo, después de un año él fue despedido de su puesto y el instituto cerrado. Georg Leidenberger, "Todo aquí es vulkanisch. El arquitecto Hannes Meyer en México, 1938 a 1949", en Congreso de historiadores de México, Estados Unidos y Canadá mexeuACan 20ro, México, El Colegio de México, en prensa. Para la cita de Chacón, véase Arquitectura, núm. 3, julio de I939, p. 57.

67. Meyer, "El arquitecto soviético", Arquitectura, núm. 9, enero de 1942, especialmente la p. 30; Manuel Chacón, "Arquerías", Arquitectura, núm. 8, julio de 194I. Otros textos de Meyer en la revista fueron "El regionalismo en la edificación de la vivienda suiza", Arquitectura, núm. 7, mayo de 194I, y "El hogar infantil cooperativo en Mümliswil (Jura, Suiza)", Arquitectura, núm. 8, julio de 194I. Louise Noelle también cita el caso de Meyer como ejemplo de la apertura ideológica de la revista. Noelle, "Estudio introductorio", op. cit., p. 35.

El enfoque pluralista de Arquitectura permite, por lo menos al lector historiador, detectar puntos en común entre posicionamientos sobre la arquitectura moderna aparentemente opuestos. Por ejemplo, junto a un artículo de Meyer apareció otro de Villagrán García donde éste afirmaba que la "voluntad de la forma iba más allá [es decir, era independiente] de la utilidad". Si bien Meyer no hubiera suscrito esta declaración, en su propio artículo, de facto, expresaba su apreciación por el elemento de la armonía en la construcción. Decía Meyer: "Lo que el músico produce mediante el tono y el silencio, el ritmo y el volumen, a saber, la 
Pani, por su parte, se posicionó por encima de estas polémicas. Si bien demostró sus simpatías con el punto de vista de los "esteticistas" (al denunciar, por ejemplo, el "funcionalismo brutal" reinante en México), ${ }^{68}$ en general asumió una postura pragmática según la cual lo importante era simplemente construir de una manera congruente con la tarea social, "revolucionaria", de la nación. En términos concretos, esto significaba brindar un servicio esencialmente material en aras de "formar el hogar del trabajador". ${ }^{69}$ Cabe destacar que esta actitud objetiva de Pani y su revista —en el sentido de querer reflejar en las páginas lo que sucedía dentro del movimiento moderno-y pragmática — de querer evitar posturas supuestamente sectarias— también constituía, a su manera, una postura ideológica, congruente con la de los gobiernos "desarrollistas" de la posguerra, los cuales, sin abandonar el discurso revolucionario social, dejaron atrás la política radical explícitamente distributiva del sexenio de Lázaro Cárdenas para lanzar medidas orientadas al crecimiento industrial con amplio involucramiento del capital nacional y foráneo.

En todo caso, la publicación de Pani derivó en parte su autoridad y fama de su aparente independencia institucional. Es decir, como no estaba financiada por el gremio de arquitectos, a la revista le era más fácil trascender ciertas luchas sectarias, y como no estaba asociada a una industria en particular, parecía más desinteresada que una revista como Cemento. Sin embargo, Arquitectura-México no carecía de intereses institucionales, sólo que en este caso se trataba de una institución por establecerse y que se llamaba "Pani".

Tomamos el caso de la cobertura de una sola obra de construcción, el hotel Reforma, para ver cómo Arquitectura-México, tanto en sus exposés como en sus anuncios, contribuyó a fomentar la familia-institución Pani. Primer acto: en la sección de anuncios del número io (julio de 1942) aparece un anuncio de la

vivencia de una sucesión musical de espacio, lo alcanza el arquitecto con medios plásticosconstructivos: una vivencia espacial en el paisaje, plasmada conscientemente".

68. De Garay, op. cit., pp. 265-296, especialmente p. 285. Al adoptar esta "vía media", Pani dio continuidad a su aprendizaje en la École des Beaux-Arts, donde él y Kaspé habían estudiado con el maestro Georges Gromort, quien era conocido por su funcionalismo formalista y clasicista. Arquitectura, núm. 5, abril de 1940, s. p.

69. Arquitectura, núm. 5, abril de 1940; De Garay, op. cit., p. 285. No todas las posturas de la revista eran conciliatorias o pragmáticas. Por ejemplo, durante el XVI Congreso Internacional de Planificación y de la Habitación de 1938, los editores criticaron, de forma indirecta, a su principal organizador, Carlos Contreras: "como era de esperarse, no se cosechó nada en efectivo para nuestro país", no obstante "las bellas palabras, las actitudes arrogantes, las gesticulaciones del súper-orador”. Arquitectura, núm. 2, abril de 1939, p. 57. 

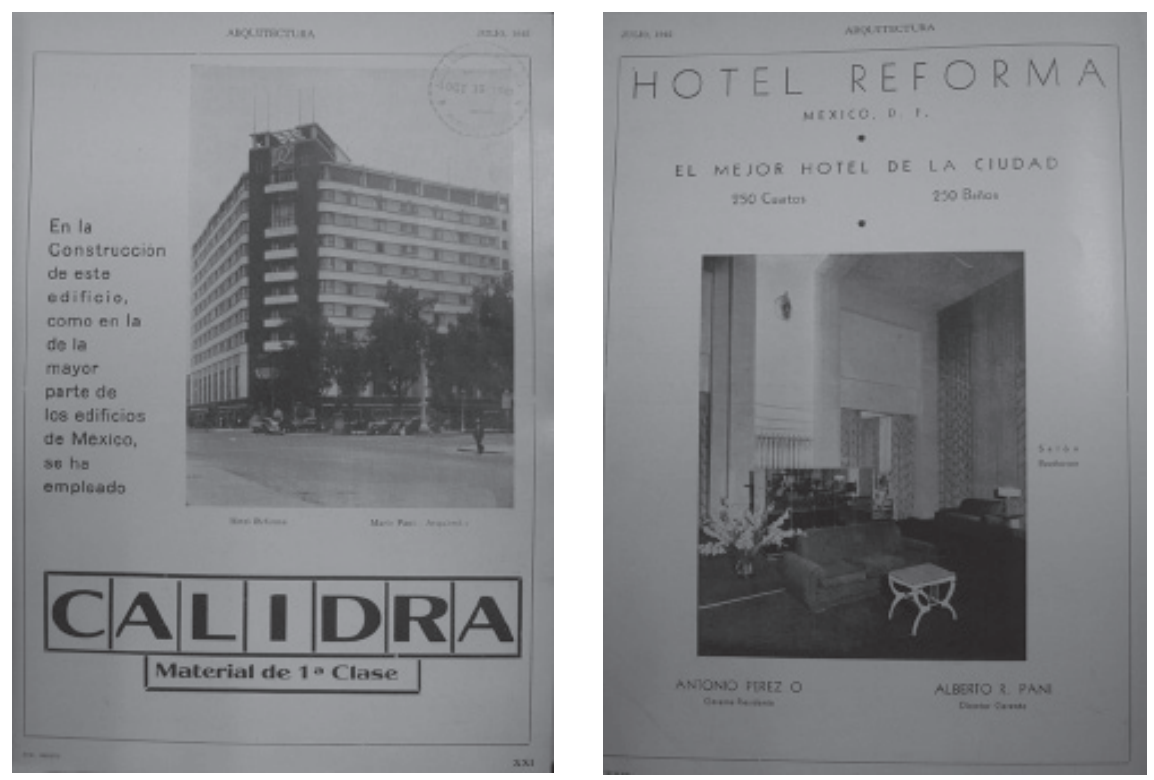

6a) Anuncio de Calidra-hotel Reforma, Arquitectura, núm. Io, julio de I942, p. xxi; b) anuncio del hotel Reforma, Arquitectura, núm. Io, julio de 1942, p. xxxii.

empresa de construcción Calidra con una amplia fotografía del recién inaugurado recinto donde vemos escrito: "En la construcción de este edificio [...] se ha empleado Calidra, [...] Hotel Reforma Mario Pani-Arquitecto" (fig. 6a). El aspecto del anuncio se parece a los artículos de fondo de la revista: predomina la fotografía acompañada por un poco de texto en una hoja que, por lo demás, está en blanco; es decir, ofrece una estética nítida, austera, moderna. La misma ambigüedad entre anuncio y artículo opera respecto a su contenido: hay una clara intención publicitaria en promover el producto Calidra, pero a su vez se informa sobre la existencia del nuevo edificio, de su arquitecto y del servicio que ofrece. El hotel Reforma, ubicado en la principal avenida de la capital, sería uno de los dos mejores hoteles de la ciudad de México de los ańos cuarenta. ${ }^{\circ}$

Segundo acto: en un número de Arquitectura de dos años atrás se publica un artículo sobre la misma empresa, Calidra, donde se informa acerca de su

70. Arquitectura, núm. ıo, julio de 1942, p. xxi; Stephen R. Niblo, México en los cuarenta: modernidad y corrupción, México, Océano, 2008, p. 49. 
planta abastecedora de cal. ${ }^{\text {I }}$ Ahora se trata de un artículo de fondo, que sin embargo contiene un claro elemento publicitario.

Tercer acto: en el ya referido número Io, cerca del anuncio de Calidra aparece un anuncio del mismo hotel con una amplia fotografía del interior del lobby acompañada por el texto: "Hotel Reforma, Ciudad de México, D.F., el mejor hotel de la ciudad [...] Antonio Pérez O., gerente residente, Alberto R. Pani, director gerente" (fig. 6b). Si en la publicidad de Calidra nos enteramos de la autoría arquitectónica del hotel, en ésta de la empresa hotelera conocemos la identidad de su dueño: Alberto Pani, quien era tío de Mario Pani y una figura destacada de la política y la ingeniería nacionales. ${ }^{72}$

Asociar, en la revista de 1942, el hotel Reforma con su dueño Alberto Pani y su arquitecto Mario Pani era particularmente significativo en relación con un intenso conflicto, que había sucedido unos ańos atrás, acerca de quién era el autor legítimo de la obra. Al inaugurarse el hotel en I936, el ya mencionado arquitecto Carlos Obregón Santacilia cuestionó la autoría de Pani con el argumento de que él mismo había diseñado la estructura del edificio y llevado a cabo la cimentación. Además, Obregón Santacilia acusó a su patrón Alberto Pani de haberle quitado a él, entonces quizá la figura más destacada de la arquitectura nacional, de la conducción de la obra de manera súbita para ponerla en manos de su joven y recién titulado sobrino. La controversia cundió también dentro del gremio y hasta llegó a ocasionar la renuncia del presidente de la SAM en protesta por la destitución de Obregón Santacilia. ${ }^{73}$ En fin, fue una álgida pugna sobre temas tan fundamentales como la ética de la práctica profesional —en este caso, de la dudosa manera como le fue retirado un proyecto a un integrante del gremio para entregarlo a otro- y la definición de autoría de una obra. Visto a la luz de esta controversia, para Mario Pani era sumamente importante asociar el edificio en cuestión con su nombre y lo logró por medio de su revista. ${ }^{74}$

71. Arquitectura, núm. 6, julio de 1940, p. 63.

72. Arquitectura, núm. Io, julio de 1942, p. xxxii. Alberto Pani ocupó cargos como secretario de Instrucción Pública, de Industria y Comercio, de Relaciones Exteriores y de Hacienda durante los sexenios de Álvaro Obregón, Plutarco Elías Calles, Pascual Ortiz Rubio y Abelardo Rodríguez. De Garay, op. cit., pp. 277-278.

73. De Garay, op. cit., pp. 282-283. Este debate era una continuación de la polémica de las "Pláticas" de I933, con la diferencia de que en I933 se discutía el contenido de la construcción y ahora se debatían las reglas de conducta de la profesión.

74. En la historiografía actual prevalecen referencias contrarias de la autoría del hotel Re- 
Estos diversos artículos-anuncios sobre el hotel Reforma en ArquitecturaMéxico indican la imprecisión de la línea que demarcaba lo informativo-sustancial de lo promocional. Se presentan los nuevos edificios significativos de la capital al mismo tiempo que se ofrecen productos en venta: materiales de construcción, hoteles y, no menos importante, arquitectos. Abundan en la revista artículos dedicados a las obras de Mario Pani — según Louise Noelle, fueron 6I a lo largo de la existencia de la revista_-75 a la vez que hay una gran cantidad de anuncios de diversas empresas (como operadores de edificios, productores de materiales de construcción y agencias de bienes raíces) que hacen mención del arquitecto. También el hermano de Mario, Arturo, editor de la sección de "Decoración", aparece mencionado en numerosos anuncios de muebles fabricados por su empresa De la Peńa y Pani. ${ }^{76}$

Esta abundancia de los Pani en los artículos y anuncios de ArquitecturaMéxico revela que la institucionalidad y los intereses materiales de la revista eran inseparables de su contenido, no obstante el declarado afán de los editores de constituir una publicación más objetiva que otras. ${ }^{77}$ Como argumenta Graciela de Garay, Mario Pani, arquitecto joven y poco conocido en México, vio en su revista un medio par excellence para perfilarse en el escenario nacional de la posguerra frente al gremio de arquitectos, la opinión pública y el Estado. ${ }^{78}$ La antes discutida pluralidad e inclusividad de enfoques de sus páginas tam-

forma. Mientras un ensayo sobre Carlos Obregón Santacilia atribuye el edificio a este arquitecto, otro, sobre Mario Pani, publicado en el mismo volumen, lo asigna a este último. Carlos G. Mijares Bracho, "La arquitectura de Carlos Obregón Santacilia", en Burian, La modernidad, op. cit., p. I57; Louise Noelle, "La arquitectura y el urbanismo", op. cit., p. I8o.

75. Noelle, "Estudio introductorio", op. cit., p. 27. Por ejemplo, una empresa de bienes raíces se anunció, con una fotografía del edificio de avenida Chapultepec esquina con Toledo, firmada por Mario Pani, en el número I I, diciembre de I942, p. xviii.

76. Véase por ejemplo, el número ıo, julio de I942, p. xviii. Otro destacado miembro de la familia involucrado en la revista fue el padre de Mario, el ingeniero Arturo Pani, quien fungió como editor fundador de la revista. El ingeniero Pani fue diplomático de I918 a 1934, cuando terminó su carrera debido a un rompimiento con el callismo. De Garay, op. cit., p. 278.

77. La dependencia económica de la revista con los anunciantes y con la propia actividad profesional de su director resultó evidente al final de la publicación, que dejó de circular, en 1978 , debido a la falta de anuncios, lo cual fue producto del paulatino retiro de Pani del ámbito de la construcción. Entrevista con Louise Noelle en De Garay, op. cit., pp. 293-294.

78. Para De Garay, la revista representa un paso clave entre varios en el camino ascendente del arquitecto Pani hacia un protagonismo en la construcción nacional; los otros fueron la ya mencionada polémica con Carlos Obregón Santacilia (entre 1934 y 1936), la exitosa participación de Pani en concursos de construcción como la Casa de España (en I939), su entrada 
poco carece por completo de una dimensión "interesada". Según De Garay, Pani demostró una "gran habilidad política" al incluir en su revista los escritos de sus competidores. Es el caso, por ejemplo, de su trato con Villagrán García, quien en 1934, como director de la Escuela de Arquitectura de la UNAM, negó la solicitud que hizo Pani para acreditar sus estudios en Francia. No obstante este hecho, o quizá por este hecho, Pani decidió abrirle a Villagrán García las páginas de su revista. ${ }^{79} \mathrm{Al}$ señalar el lado promocional de Arquitectura, no se pretende menospreciar o cuestionar la calidad de la que efectivamente es una de las más aclamadas publicaciones del campo, sino más bien identificar los lazos institucionales y los intereses materiales de la publicación, un aspecto que se subrayó respecto a las otras revistas incluidas en este trabajo.

\section{Conclusiones}

Este análisis de tres revistas mexicanas que fueron protagonistas en las discusiones teóricas y de la exposición de obras y tendencias acerca de la arquitectura entre los ańos veinte y cuarenta del siglo pasado brindó la oportunidad de ver cómo se ubicaron las publicaciones frente a dos temáticas clave de su momento: el movimiento moderno de arquitectura, que entonces destacaba por su cosmopolitismo, y la Revolución mexicana, que teñía las discusiones sobre la política y sobre el discurso de la nación. Al muy tenue y esencialmente cerrado acercamiento hacia la construcción moderna por parte de El Arquitecto, Cemento respondió con una apertura radical frente a las tendencias vanguardistas. Por último, Arquitectura-México, con la ventaja de aparecer casi una década después, cuando el movimiento había adquirido cierta aceptación en el ámbito de la construcción, asumió una postura de refinamiento y pragmatismo hacia las vanguardias; la revista aceptó las vanguardias como elemento básico de la construcción sin caer en los debates polarizados en que antes se situaban. A su vez, las revistas se posicionaron frente a la cuestión nacional. El Arquitecto adoptó una postura expresamente nacionalista, según la cual habría que abrazar las corrientes internacionales solamente en cuanto lo exigían las necesidades de la patria, actitud ésta que resultó en una escasa

como maestro en la UnAM (en 1940) y, finalmente, su destacada participación en la construcción de la Ciudad Universitaria (a partir de 1950). De Garay, op. cit., pp. 280-290.

79. Ibidem, pp. 270-273. 
atención a las tendencias foráneas; por su parte, Cemento y Tolteca demostraron una franca apertura a las construcciones extranjeras, y, por último, Arquitectura-México se ubicó en un declarado internacionalismo al mismo tiempo que resaltaba los avances de la construcción en casa propia.

La manera como las tres revistas incorporaron la modernidad arquitectónica internacional — siempre ligada con y filtrada por las exigencias de la época posrevolucionaria nacional- es representativa de las tendencias, en general, del campo arquitectónico y de la construcción en México. La aportación de las revistas en este sentido nos brinda mayor sustancia y también genera preguntas acerca de la narrativa historiográfica sobre los orígenes de la arquitectura moderna en México. El caso de la revista de la SAM, El Arquitecto, reafirma la irrupción relativamente tardía de un lenguaje moderno en México a finales de los ańos veinte. Queda abierta la pregunta del porqué de esta resistencia a incorporar con mayor ímpetu las propuestas modernas de los colegas europeos, sobre todo en vista de que en ambas partes del mundo se estaba enfrentando una problemática social y política parecida: cómo proporcionar "buenas" construcciones a las masas y no solamente a las clases privilegiadas. El caso de Cemento y Tolteca revela que al lado de la relativa cerrazón del gremio profesional había un amplio interés en hacer llegar a los lectores (que por cierto eran más numerosos y diversos que los de la revista de la SAM) la nueva construcción y, claro está, el nuevo material en que ésta se basaba. Fue el sector privado, industrial —y no el gremial, profesional o el estatal — el que asumió un papel protagónico al presentar la modernidad arquitectónica internacional al público mexicano. Finalmente, nuestra lectura de la revista de Pani, Arquitectura-México, revela una plena aceptación y promoción de dicha modernidad, pero con el acento puesto en que ésta fuera congruente con el proyecto social del régimen político.

Para Mario Pani, Federico Sánchez Fogarty y Alfonso Pallares, los destacados editores y directores de nuestras revistas, la cuestión de cómo enfrentar la modernidad en México estaba ligada con sus intereses personales y los de las instituciones que representaban. Y, claro está, con el interés de mantener a flote sus publicaciones, cuyas precarias existencias iban y venían junto con determinadas circunstancias históricas, a excepción de Arquitectura-México que perduraría por muchas décadas, hasta los setenta, a través de los avatares históricos. Al examinar la historia de la arquitectura por medio de la revista, nos percatamos de la importancia que tuvieron los factores materiales, institucionales y políticos en la evolución de las ideas y las prácticas de la construcción moderna en México. 
Finalmente, estudiar las revistas de arquitectura sirve para trascender un enfoque en el gran arquitecto y su obra. La práctica arquitectónica también era una labor intelectual; en las páginas de las revistas se intercambiaron ideas sobre el buen construir y sus implicaciones sociales y políticas. A su vez, ser arquitecto requería la tarea de promoción, entendida en un sentido amplio; el estudio de estas revistas dirige nuestra atención hacia la esfera pública como un espacio de comunicación, donde los arquitectos tuvieron que justificar el servicio profesional que brindaban y en el cual también eran sujetos a críticas y cuestionamientos. De tal manera, el enfoque en las revistas ofrece un buen ejemplo de una perspectiva intelectual y política de la historia arquitectónica. \$

N.B. Elaboré este texto a partir de la ponencia que presenté en el Coloquio Internacional Las Revistas en la Historia Intelectual de América y España (Cuerpo Académico de Historia Intelectual, Universidad Autónoma Metropolitana-Cuajimalpa), que se llevó a cabo del 26 al 28 de enero de 20 i . Agradezco la amable atención que me brindó Louise Noelle durante la investigación de este trabajo y doy las gracias a Concepción Christlieb Robles, coordinadora de la Biblioteca de la Facultad de Arquitectura de la UNAM, por su apoyo para ubicar las revistas. Gracias también a los dictaminadores del manuscrito. Agradezco asimismo la corrección de estilo que realizó Yael Bitrán.

* Artículo recibido el 28 de octubre de 20 I , aceptado el 27 de agosto de 2012. 